\title{
EFFECT OF FLUX COMPOSITION ON THE PERCENTAGE ELONGATION AND TENSILE STRENGTH OF WELDS IN SUBMERGED ARC WELDING
}

\begin{abstract}
This experimental study reveals the effects of $\mathrm{CaF}_{2}, \mathrm{FeMn}$ and $\mathrm{NiO}$ additions to the base fluxes on tensile strength and percentage elongation of the weld metal. The aim of this study is to develop suitable flux for mild steel for high tensile strength, impact strength and ductility. Bead on plate welds were made using submerged arc welding process. Mathematical model for percentage elongation and UTS of mild steel welds were made. The elements transfer to the welds have been correlated with the above mechanical performance characteristics. The effect of oxygen content on weld elongation and UTS also has been deduced. This study shows that $\mathrm{CaF}_{2}$ and $\mathrm{NiO}$ are the significant factors for tensile strength while FeMn is not significant for tensile strength. However, for elongation besides $\mathrm{CaF}_{2}$, the interaction of $\mathrm{CaF}_{2}$ and FeMn was also found significant. The effects of basicity index of the flux and carbon equivalent of the welds on tensile strength and percentage elongation of the welds have also been evaluated.
\end{abstract}

\section{Introduction}

Submerged arc welding is a process that melts and joins metals by heating them with an arc established between a consumable wire electrode and the metals, with the arc being shielded by a molten slag and granular flux. This welding process differs from the other welding processes in that the arc is

\footnotetext{
${ }^{1}$ Maharaja Surajmal Institute of Technology, Janakpuri, New Delhi, India; Email: brijpalsingh101@gmail.com

${ }^{2}$ Jamia Milia Islamia University, Jamia Nagar, New Delhi, India

${ }^{3}$ Netaji Subhas Institute of Technology, Dwarka, New Delhi, India
} 
submerged and invisible. The flux is supplied from a hopper, which travels with the torch. No shielding gas is needed because the molten metal is separated from the air by molten slag and granular flux.

Submerged arc welding is widely used in the fabrication of pressure vessels, pipe lines and offshore structures because of its higher metal deposition rate, good strength of the joint and good surface appearance [1-3]. The properties of the welded joint, such as strength, toughness and ductility, can be improved by controlling the microstructure of the welded joint. The ductility is a measure of degree of plastic deformation that the weld metal can sustain before fracture. If the ductility of the weld is poor, the weld will be brittle and the strength and toughness both will be poor. So, in this study an attempt has been made to correlate the ductility of the weld with the flux composition. For design of structural components or machines, it is essential to know how much plastic deformation will be experienced before the fracture. It may be measured by percentage elongation or area reduction of tensile specimen. The weld metal chemistry is mainly affected by transfer of elements to or from the slag which is mainly decided by the flux composition and operating variables [4-7].

\section{Literature review}

The flux composition plays a vital role in submerged arc welding. It affects the weld physically, chemically and metallurgically. The stability of arc, quality of weld joint and properties are decided by the flux composition. The mechanical properties of the weld metal are decided by the composition of the weld, the elements transferred to the weld during SAW, inclusions found and the microstructure developed. The main elements that decide the mechanical properties strength, ductility, hardness and toughness are $\mathrm{C}, \mathrm{Si}, \mathrm{Mn}, \mathrm{Ni}, \mathrm{S}$ and $\mathrm{P}$.

Manganese increases the hardness and tensile strength of the steel to a certain extent but reduces the ductility of the weld metal. However, the source of addition of $\mathrm{Mn}$ also has a great influence on mechanical properties of the weld. The weld Mn and Si both may be added to the weld either from the flux or from the wire or base plate but if these are added from the flux, the mechanical properties such as impact strength and ductility both are reduced [8]. This may be because of higher oxygen present in weld which may be generated because of disassociation of oxides in the flux. Weld Mn also increases the rate of carbon penetration during carburizing and acts as a mild deoxidizing agent. It also reduces the necessary carbon content for getting high strength in the weld. When $\mathrm{Mn}$ and $\mathrm{C}$ contents are too high, embrittlement of the weld takes place. The weld Mn also reacts with sulphur and forms MnS, which may reduce the chances of hot cracking. The ratio of $\mathrm{Mn} / \mathrm{S}$ should be greater than 50 for 
reducing the chances of cracking [9]. The weld Mn content has a specific range for optimum strength and hardness. It is also established that impact strength and ductility both are proportional to each other [10]. The weld Mn content also works as deoxidizer and desulphurizer in the weld metal. A decrease in the oxygen content in the weld metal can be achieved through a higher $\mathrm{Mn} / \mathrm{Si}$ ratio [11].

Silicon is added to the weld for high tensile strength but it is assumed that it does not favor for impact strength, particularly the transition temperature. With decreasing acidity or oxygen content, the mechanical properties are improved. Deoxidizing elements like $\mathrm{Al}$ and $\mathrm{Ca}$ improves impact strength. Silicon improves strength and hardness, but to a lesser extent than Mn. It is used as a deoxidizer and makes sound welds. Silicon causes a loss of ductility and if it is higher than $0.5 \%$, it causes a loss of impact strength [12].

The atmospheric gases oxygen, nitrogen and hydrogen also affect the ductility of the weld by reacting with the elements present in the weld. Oxygen reacts with the aluminium present in the weld and forms inclusions which are supposed to be harmful for ductility. In the same way, nitrogen also reacts with the elements present in the weld and forms hard nitrides and reduces the ductility. The increase of oxygen in the weld metal is susceptible to brittle fracture [13]. The inclusions present in the weld also affect the ductility and other properties. The shape and size of inclusions also affect the toughness and plasticity. The globular shape is most favourable for toughness and ductility. The oxygen content is decided by the disassociation of flux oxides or by the basicity index of the flux. This depends on the stability of the oxides of the fluxes during the welding. Stable oxides generate less oxygen while non-stable produces high oxy gen in the weld. However, some stable oxides like $\mathrm{SiO}_{2}$ decompose in to sub oxides and generate more oxygen [14].

The mechanical properties of the weldments are also decided by the microstructure developed during submerged arc welding [15]. The microstructure of the weld metal is decided by the heating and cooling cycle [16]. The optimum mechanical properties may be obtained by proper selection of flux. The microstructure also depends on the heat input and cooling rate [17, 18]. The austenite to ferrite transformation, cooling rate and different ferrite morphologies are important considerations for improving the mechanical properties. The various microstructures formed in the low carbon steel welds are grain boundary ferrite, widmanstatten ferrite, side-plate ferrite and micro phases (a small amount of martensite, retained austenite or degenerated pearlite) depending on the cooling rate and composition [19]. 


\section{Experimental procedure}

In this study, twenty fluxes were designed by using central composite design using response surface methodology, as shown in Table 1. The base fluxes $\mathrm{CaO}-\mathrm{SiO}_{2}-\mathrm{Al}_{2} \mathrm{O}_{3}$ were designed based on binary and ternary phase diagrams. The base fluxes were prepared in the ratio of 7:10:2. The alloying substances $\mathrm{CaF}_{2}, \mathrm{FeMn}$ and $\mathrm{NiO}$ were added in the range of $(2-8) \%$ to the base fluxes to study the effect of $\mathrm{C}, \mathrm{Si}, \mathrm{Mn}, \mathrm{S}$, and $\mathrm{Ni}$ transfer on the weld metal properties such as impact strength and elongation. The three factors are given in Table 2. For this study, bead on plate welds were made from the different twenty fluxes. The welding parameters were decided on the basis of a pilot experiment and

Design matrix in coded form

\begin{tabular}{|c|r|r|r|}
\hline No. of Experiment & $\mathbf{C a F}_{\mathbf{2}} \mathbf{w t}$ \% $\mathbf{A}$ & $\mathbf{F e M n} \mathbf{w t}$ \% B & $\mathbf{N i O} \mathbf{w t}$ \% $\mathbf{~}$ \\
\hline 1 & +1 & -1 & -1 \\
\hline 2 & 0 & +1 & 0 \\
\hline 3 & +1 & -1 & +1 \\
\hline 4 & -1 & -1 & -1 \\
\hline 5 & 0 & 0 & 0 \\
\hline 6 & 0 & 0 & 0 \\
\hline 7 & +1 & +1 & +1 \\
\hline 8 & 0 & 0 & 0 \\
\hline 9 & 0 & -1 & 0 \\
\hline 10 & +1 & 0 & 0 \\
\hline 11 & 0 & 0 & +1 \\
\hline 12 & -1 & -1 & +1 \\
\hline 13 & 0 & 0 & 0 \\
\hline 14 & 0 & 0 & 0 \\
\hline 15 & +1 & +1 & -1 \\
\hline 16 & -1 & 0 & 0 \\
\hline 17 & 0 & 0 & 0 \\
\hline 18 & 0 & 0 & -1 \\
\hline 19 & -1 & +1 & +1 \\
\hline 20 & -1 & +1 & -1 \\
\hline
\end{tabular}

Table 1.

Table 2.

The three factors and their levels

\begin{tabular}{|c|c|c|c|c|}
\hline Factors & Additives & Lower Level \% & Middle Level \% & High Level \% \\
\hline $\mathrm{A}$ & $\mathrm{CaF}_{2}$ & 2 & 5 & 8 \\
\hline $\mathrm{B}$ & $\mathrm{FeMn}$ & 2 & 5 & 8 \\
\hline $\mathrm{C}$ & $\mathrm{NiO}$ & 2 & 5 & 8 \\
\hline
\end{tabular}


these were made as constant. The composition of wire and base plate is given in Table 3. The tensile test specimens were made on lathe machine and the tensile test were performed on extensometer in mechanical Engineering Department Jamia Millia Islamia Delhi. The measured mechanical properties of the welds and the various elements transferred to the welds are given in Table 4. The transfer of $\mathrm{Mn}$ and $\mathrm{Ni}$ contents was calculated from the following relation: The transfer of manganese content was calculated by a $\Delta$ Delta quantity $=$ = Analyzed composition - Expected composition .

Table 3 .

The wire and plate composition

\begin{tabular}{|c|c|c|c|c|c|c|}
\hline Composition & $\begin{array}{c}\text { Carbon } \\
\mathbf{\%}\end{array}$ & $\begin{array}{c}\text { Silicon } \\
\mathbf{\%}\end{array}$ & $\begin{array}{c}\text { Manganese } \\
\mathbf{\%}\end{array}$ & $\begin{array}{c}\text { Sulphur } \\
\mathbf{\%}\end{array}$ & $\begin{array}{c}\text { Phosphorus } \\
\mathbf{\%}\end{array}$ & $\begin{array}{c}\text { Nickel } \\
\mathbf{\%}\end{array}$ \\
\hline Base Plate & 0.03 & 0.07 & 0.34 & 0.017 & 0.022 & - \\
\hline Wire & 0.11 & 0.09 & 0.45 & 0.021 & 0.021 & - \\
\hline
\end{tabular}

Table 4.

UTS and elongation of various welds

\begin{tabular}{|c|c|c|c|c|c|c|c|c|c|c|c|}
\hline Flux & $\mathrm{CaF}_{2}$ & $\mathrm{FeMn}$ & $\mathrm{NiO}$ & $\mathrm{C}$ & $\mathrm{Mn}$ & $\mathrm{Si}$ & $\mathrm{Ni}$ & & Carbon & UTS & Elongation \\
\hline 1 & 8 & $\%$ & $\%$ & $\%$ & $\%$ & $\%$ & $\%$ & $\Delta \mathrm{Mn}$ & Eq. & $\mathrm{MPa}$ & $\%$ \\
\hline 2 & 5 & 2 & 2 & 0.03 & 0.17 & 0.01 & 0.177 & -0.267 & 0.045 & 270.0 & 19.76 \\
\hline 3 & 8 & 2 & 8 & 0.04 & 0.23 & 0.10 & 0.544 & -0.209 & 0.064 & 320.2 & 26.16 \\
\hline 4 & 2 & 2 & 2 & 0.04 & 0.17 & 0.10 & 0.374 & -0.267 & 0.058 & 189.8 & 7.00 \\
\hline 5 & 5 & 5 & 5 & 0.04 & 0.35 & 0.10 & 0.388 & -0.089 & 0.067 & 300.0 & 10.00 \\
\hline 6 & 5 & 5 & 5 & 0.08 & 0.31 & 0.02 & 0.250 & -0.129 & 0.100 & 320.0 & 9.80 \\
\hline 7 & 8 & 8 & 8 & 0.04 & 0.38 & 0.10 & 0.477 & -0.059 & 0.070 & 190.7 & 8.86 \\
\hline 8 & 5 & 5 & 5 & 0.08 & 0.34 & 0.02 & 0.270 & -0.099 & 0.102 & 284.7 & 10.33 \\
\hline 9 & 5 & 2 & 5 & 0.03 & 0.34 & 0.14 & 0.474 & -0.099 & 0.060 & 280.1 & 11.41 \\
\hline 10 & 8 & 5 & 5 & 0.04 & 0.42 & 0.11 & 0.744 & -0.019 & 0.077 & 292.6 & 21.03 \\
\hline 11 & 5 & 5 & 8 & 0.04 & 0.15 & 0.10 & 1.330 & -0.289 & 0.073 & 240.0 & 6.90 \\
\hline 12 & 2 & 2 & 8 & 0.03 & 0.57 & 0.10 & 0.440 & 0.131 & 0.069 & 175.7 & 5.82 \\
\hline 13 & 5 & 5 & 5 & 0.07 & 0.38 & 0.03 & 0.320 & -0.059 & 0.095 & 330.9 & 10.10 \\
\hline 14 & 5 & 5 & 5 & 0.04 & 0.34 & 0.11 & 0.320 & -0.049 & 0.066 & 326.5 & 16.20 \\
\hline 15 & 8 & 8 & 2 & 0.04 & 0.24 & 0.10 & 0.054 & -0.199 & 0.056 & 351.0 & 9.20 \\
\hline 16 & 2 & 5 & 5 & 0.04 & 0.25 & 0.14 & 0.344 & -0.189 & 0.063 & 152.3 & 15.65 \\
\hline 17 & 5 & 5 & 5 & 0.03 & 0.50 & 0.10 & 0.452 & 0.061 & 0.066 & 319.5 & 15.60 \\
\hline 18 & 5 & 5 & 2 & 0.04 & 0.29 & 0.10 & 0.366 & -0.149 & 0.064 & 351.0 & 7.87 \\
\hline 19 & 2 & 8 & 8 & 0.04 & 0.33 & 0.10 & 0.502 & -0.109 & 0.068 & 128.8 & 13.25 \\
\hline 20 & 2 & 8 & 2 & 0.04 & 0.33 & 0.10 & 0.288 & -0.109 & 0.065 & 319.5 & 13.68 \\
\hline
\end{tabular}


The expected composition was calculated from the below given relation.

$\left(\begin{array}{l}\text { Expected } \\ \text { composition }\end{array}\right)=\frac{\text { dilution } \cdot\left(\begin{array}{l}\text { base plate } \\ \text { composition }\end{array}\right)+(100-\text { dilution }) \cdot\left(\begin{array}{l}\text { wire } \\ \text { composition }\end{array}\right)}{100}$

The ANOVA Table 5 shows that $\mathrm{CaF}_{2}$ and $\mathrm{NiO}$ both are having significant effect on tensile strength. The term FeMn is not significant for UTS. This suggests a quadratic model for the tensile strength. The developed equation for tensile strength is given below in equation (1). The UTS is given in MPa.

This equation is given in terms of actual factors.

$$
\left(\begin{array}{c}
\text { Ultimate } \\
\text { Tensile } \\
\text { Strength }
\end{array}\right)=\begin{aligned}
& -79.29+99.96 \mathrm{CaF}_{2}+38.41 \mathrm{FeMn}+12.68 \mathrm{NiO}+ \\
& -1.83 \mathrm{FeMn} \cdot \mathrm{CaF}_{2}-5.38 \mathrm{FeMn} \cdot \mathrm{NiO}-7.55 \mathrm{CaF}_{2}^{2}
\end{aligned}
$$

The effect of $\mathrm{CaF}_{2}$ on UTS shows that the tensile strength increases with the increase of $\mathrm{CaF}_{2}$ additive to a certain extent but after that it is slightly reduced. This has been shown in Fig. 1. This is in agreement with the previous

ANOVA of ultimate tensile strength

\begin{tabular}{|l|c|r|c|c|c|l|}
\hline \multicolumn{7}{|l|}{ ANOVA for Response Surface Reduced Quadratic Model } \\
\hline Analysis of variance table [Partial sum of squares - Type III] \\
\hline Source & Sum of Squares & df & Mean Square & F Value & p-value Prob > F & Remarks \\
\hline Model & 83685.98 & 6 & 13947.66 & 28.303 & $<0.0001$ & significant \\
\hline A-CaF2 & 21013.06 & 1 & 21013.06 & 42.641 & $<0.0001$ & significant \\
\hline B-FeMn & 521.284 & 1 & 521.284 & 1.058 & 0.3225 & \\
\hline C-Nio & 18139.08 & 1 & 18139.08 & 36.809 & $<0.0001$ & significant \\
\hline AB & 2154.961 & 1 & 2154.961 & 4.373 & 0.0567 & \\
\hline BC & 18730.80 & 1 & 18730.8 & 38.009 & $<0.0001$ & significant \\
\hline A^2 & 23126.80 & 1 & 23126.8 & 46.930 & $<0.0001$ & significant \\
\hline Residual & 6406.342 & 13 & 492.7955 & & & \\
\hline Lack of Fit & 4844.702 & 8 & 605.5877 & 1.939 & 0.2415 & not significant \\
\hline Pure Error & 1561.64 & 5 & 312.328 & & & \\
\hline Cor Total & 90092.33 & 19 & & & & \\
\hline
\end{tabular}

\begin{tabular}{|l|l|l|r|}
\hline Std. Dev. & 22.199 & R-Squared & 0.9289 \\
\hline Mean & 273.065 & Adj R-Squared & 0.8961 \\
\hline C.V. \% & 8.130 & Pred R-Squared & 0.7599 \\
\hline PRESS & 21626.81 & Adeq Precision & 18.3361 \\
\hline
\end{tabular}

Table 5 . 


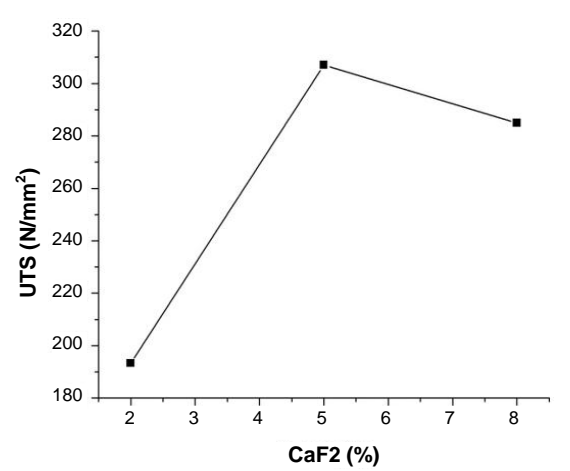

Fig. 1. Effect of $\mathrm{CaF}_{2}$ on UTS of the welds

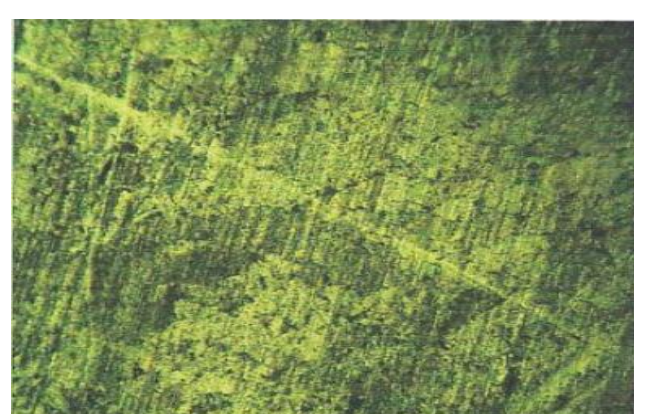

Fig. 2. Microstructure of weld No. 3, having highest pearlite content and $\mathrm{CaF}_{2}$

research [20]. The increase in UTS might be because of the effect of $\mathrm{CaF}_{2}$ on various elements transfered to the weld and increase in basicity index of the flux with increasing $\mathrm{CaF}_{2}$. The reduction in the weld $\mathrm{Mn}$ and oxygen contents also occur with increase of $\mathrm{CaF}_{2}$ [21].These two elements together also affect the tensile strength of the weld metal. The $\mathrm{C}$ and Mn transfers are also increased with the increase of the basicity index of the flux. The fluxes containing high basicity index reduces the Mn transfer from the weld to the slag [22]. The increase of $C$ and Mn contents might affect the UTS of the welds. Carbon is powerful strengthening agent in steel weld metal. However, excess carbon has adverse effect on toughness and ductility. The weld Mn content increases the UTS of the welds to a certain extent, as it promotes the fine grained structure. However, if the weld Mn content is further increased, it may reduce the tensile strength. Another reason for the increase in tensile strength may be the increase in pearlite content with increasing $\mathrm{CaF}_{2}$. Besides the flux composition, the polarity also has a significant effect on Mn transfer and mechanical properties [23]. The weldments 1, 3 and 15 all having high $\mathrm{CaF}_{2}$ also have high pearlite content. The microstructure of weld No. 3 has been shown in Fig. 2. It contains (15-20)\% pearlite in the weld.

The effect of $\mathrm{NiO}$ content shows that the tensile strength is reduced with the increase of $\mathrm{NiO}$ content in the flux. This can be seen from Fig. 3. This might be attributed to the more Ni proportion transfer to the weld, as well as increase in oxygen content with increasing $\mathrm{NiO}$ content in the flux. The $\mathrm{Ni}$ content promotes hardness and impact strength, so the tensile strength may be reduced. The large amount of oxygen content in the weld may also reduce the UTS of the weld metal. The large oxygen in the welds might be generated due to the disassociation of $\mathrm{NiO}$ into $\mathrm{Ni}$, and oxygen contents as $\mathrm{NiO}$ is a less stable oxide. The experimental results show that the tensile strength increases a little with the increase of FeMn content in the flux. This may be attributed to more Mn proportion transfer to the weld with increasing FeMn content in the 


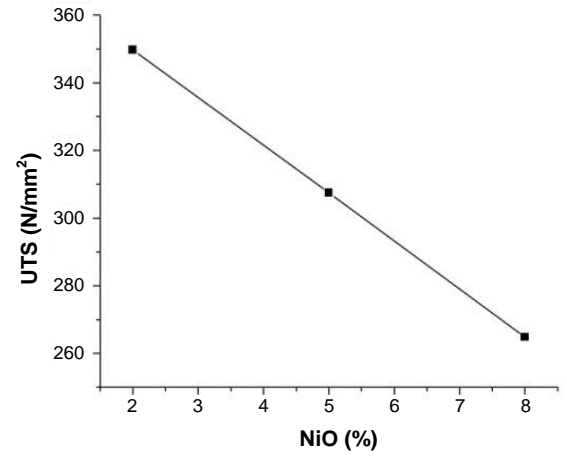

Fig. 3. Effect of $\mathrm{NiO}$ on UTS of the welds

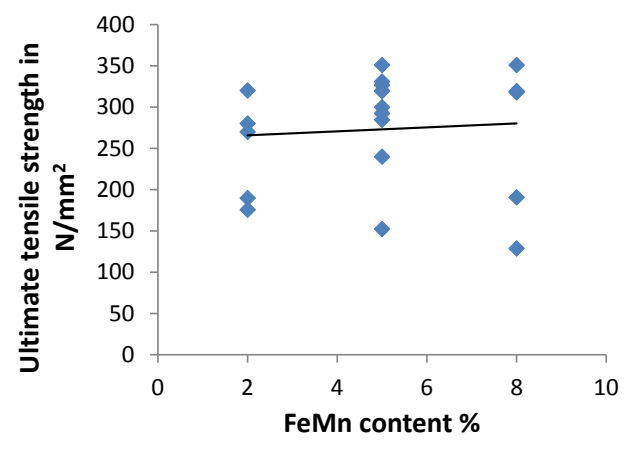

Fig. 4. Effect of FeMn on UTS of the welds

flux. Although the model shows that FeMn is not a significant factor for UTS. This is shown in Fig. 4.

The UTS of the welds also increases with the increase of carbon equivalent of the weld material as shown in Fig. 5. This shows the increasing trend because the carbon equivalent is very low for all the welds. If the carbon equivalent is high, the brittleness of the weld may increase, which may reduce the tensile strength. The possible reason for the scattering of points in Fig. 5 might be because of very low variation in CE and large changes in corresponding tensile strength. The possible reason for large variation in tensile strength may be the presence of other elements and oxygen in the welds which have not been included in CE. The carbon equivalent has been calculated by using Japanese Engineering Society formula which is given below in equation (2).

$$
\mathrm{Pcm}=\% \mathrm{C}+\% \frac{\mathrm{Si}}{30}+\% \frac{\mathrm{Mn}}{20}+\% \frac{\mathrm{Ni}}{60}
$$

The ultimate tensile strength of the welds also increases with increase of basicity index of the flux. This is shown in Fig. 6. This may be attributed to

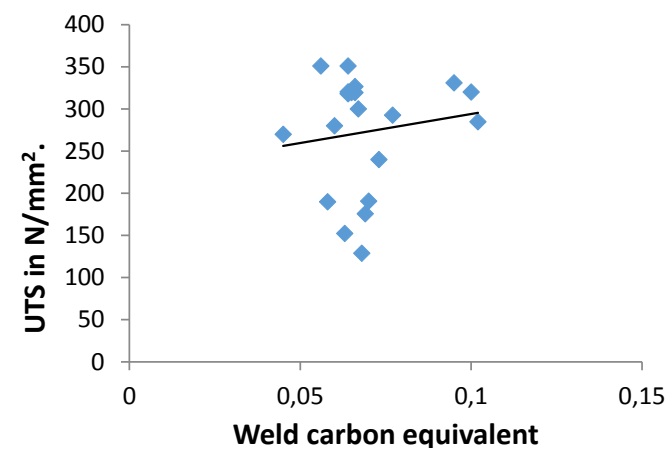

Fig. 5. Effect of CE on UTS of the welds

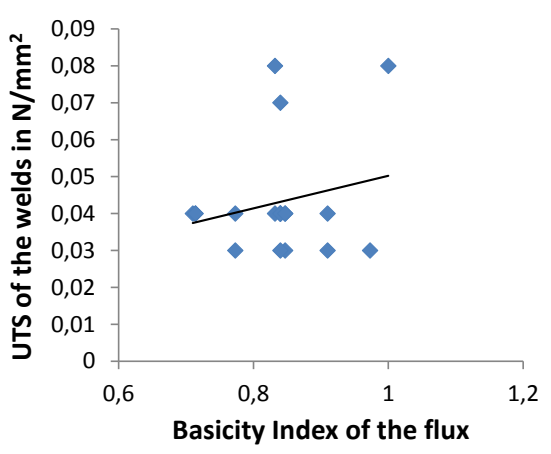

Fig. 6. Effect of BI on UTS of the welds 
the effect of basicity index on various elements transfer to the welding and its correlation with the weld oxygen. This is in agreement with the previous results [24]. However, in this study all the fluxes are acidic in nature so, the BI is changed very little. So, the points may not be so close to the fitted line in Fig. 6. The tensile strength of the welds also decreases with the increase of negative $\Delta \mathrm{Mn}$, which may be considered an indirect measurement of oxygen content in the weld. The UTS of the welds is reduced with increasing oxygen content in the weld. This can be seen from Fig. 7. The scattering of points from the fitted line shows some deviation. The probable reason may be the actual oxygen present in the weld as the oxygen content alone cannot be decided by the flux or elements transferred to the welds. The atmospheric oxygen may also affect the tensile strength, which has not been included in the analysis.

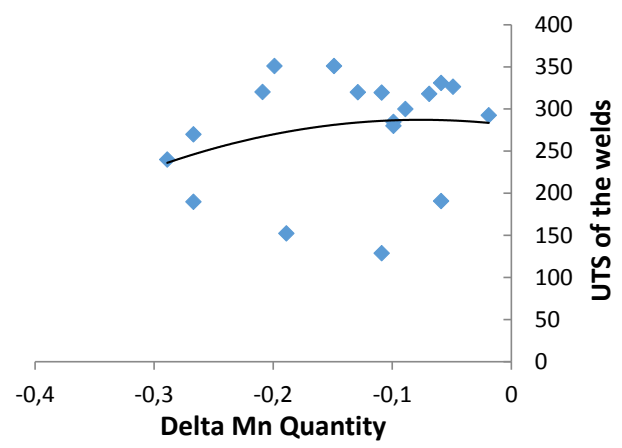

Fig. 7. Correlation of UTS with negative $\Delta \mathrm{Mn}$

\section{Correlation of UTS with Mn and Ni contents transfer}

The UTS also has been correlated with the Mn Ni and Si contents in the weld. It shows that the tensile strength increases initially with Mn content in the weld but after $0.4 \% \mathrm{Mn}$ content, the tensile strength is reduced. The optimum range may be from $0.35 \%$ to $0.39 \%$. This can be seen from Fig 8 . The Mn content promotes solid solution hardening and formation of fine grained structure [25]. When Mn content was high $0.57 \%$, the tensile strength was reduced, which may also be dueto low carbon in the weld. The maximum tensile strength was found for weld No. 15 and 18 which may also be possible because of low Ni content and optimum balance of $\mathrm{Mn}$ and carbon contents. The fitted line may have some deviation because the Mn transfer depends upon the slag metal reactions and as well as on the dilution reactions and as the temperature during SAW is very high so, it is difficult to attain the equilibrium. Thus, the transfer of elements may be affected by these reactions. Flux No. 5, $6,8,13,14$ and 17 have same composition but these show wide variation in Mn 


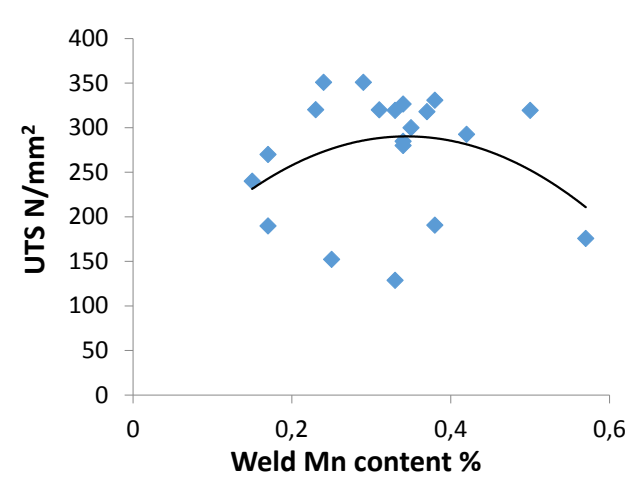

Fig. 8. Correlation of UTS of the welds with weld Mn content

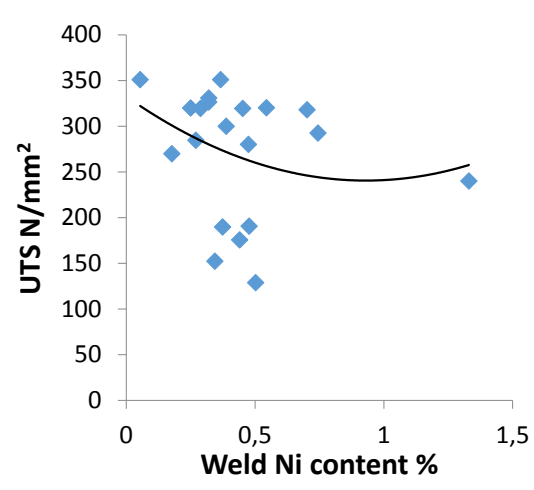

Fig. 9. Correlation of UTS with weld Ni content

content. The Ni content correlation with tensile strength shows that the UTS decreases with increasing weld $\mathrm{Ni}$ content. The weld $\mathrm{Ni}$ content may reduce the tensile strength as high Ni nickel promotes microseggregation of $\mathrm{Mn}$ at the grain boundary and reduces the Mn content in the weld [26]. This has been shown in Fig. 9. The low weld Mn content due to microseggregation may also reduce the UTS.This may also be attributed to the increase in toughness with increase of Ni contents. The tensile strength is also reduced with increase of $\mathrm{Si}$ content in the weld. This is shown in Fig. 10. Although Si content is supposed to increase the UTS but it shows a reducing trend. This might be because of very low $\mathrm{Si}$ content in most of the welds.

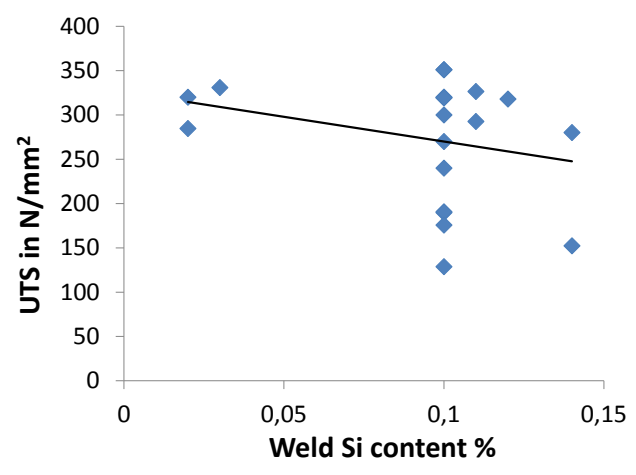

Fig. 10. Correlation of UTS with weld Si content

\section{Effect of Flux composition on percentage elongation}

The ANOVA Table 6 for percentage elongation shows that $\mathrm{CaF}_{2}$ is the only significant factor for elongation. The developed second order model for percentage elongation using surface methodology is given as in equation 3 . 
ANOVA for percentage elongation

\begin{tabular}{|l|c|r|c|c|c|l|}
\hline \multicolumn{7}{|l|}{ ANOVA for Response Surface Reduced Quadratic Model } \\
\hline Analysis of variance table [Partial sum of squares - Type III] \\
\hline Source & Sum of Squares & df & Mean Square & F Value & p-value Prob > F & Remark \\
\hline Model & 446.53 & 6 & 74.422 & 12.40 & 0.0001 & significant \\
\hline $\mathrm{A}-\mathrm{CaF}_{2}$ & 87.68 & 1 & 87.675 & 14.60 & 0.0021 & significant \\
\hline B-FeMn & 14.30 & 1 & 14.304 & 2.38 & 0.1467 & \\
\hline $\mathrm{C}-\mathrm{Nio}$ & 1.21 & 1 & 1.211 & 0.20 & 0.6607 & \\
\hline $\mathrm{AB}$ & 220.19 & 1 & 220.185 & 36.68 & $<0.0001$ & significant \\
\hline $\mathrm{A}^{\wedge} 2$ & 112.17 & 1 & 112.172 & 18.69 & 0.0008 & significant \\
\hline $\mathrm{C}^{\wedge} 2$ & 81.10 & 1 & 81.104 & 13.51 & 0.0028 & significant \\
\hline Residual & 78.04 & 13 & 6.003 & & & \\
\hline Lack of Fit & 32.20 & 8 & 4.025 & 0.44 & 0.8560 & not significant \\
\hline Pure Error & 45.84 & 5 & 9.168 & & & \\
\hline Cor Total & 524.57 & 19 & & & & \\
\hline
\end{tabular}

\begin{tabular}{|l|l|l|r|}
\hline Std. Dev. & 2.4502 & R-Squared & 0.8512 \\
\hline Mean & 12.5910 & Adj R-Squared & 0.7826 \\
\hline C.V. \% & 19.4596 & Pred R-Squared & 0.6608 \\
\hline PRESS & 177.9281 & Adeq Precision & 11.8042 \\
\hline
\end{tabular}

Here in this equation, the various terms are given in terms of actual factors

$$
\begin{aligned}
\left(\begin{array}{c}
\text { Pertencage } \\
\text { Elongation }
\end{array}\right)= & -3.48-2.68 \mathrm{CaF}_{2}+2.52 \mathrm{FeMn}+5.71 \mathrm{NiO}+ \\
& -0.582 \mathrm{CaF}_{2} \cdot \mathrm{FeMn}+0.658 \mathrm{CaF}_{2}^{2}-0.559 \mathrm{NiO}^{2}
\end{aligned}
$$

The effect of $\mathrm{CaF}_{2}$ on the elongation of the weld is shown in Fig. 11. This shows that the elongation initially decreases to a certain extent and after that it increases. However, the elongation is supposed to increase with increasing $\mathrm{CaF}_{2}$ content [27]. The trend in Fig. 11 might be attributed to the various elements transferred to the weld and the microstructure formed as a result of increased $\mathrm{CaF}_{2}$. The transfer of elements is also affected by the amount of $\mathrm{CaF}_{2}$ present in the weld. Initially, the elongation of the weld may be reduced as the weld $\mathrm{Mn}$ content might be high. Further increase of $\mathrm{CaF}_{2}$ content may reduce the weld Mn content and consequently, the elongation may be increased. The higher amount of $\mathrm{CaF}_{2}$ may also increase the basicity index of the flux and the corresponding amount of oxygen content in the weld might be reduced. The low weld oxygen also improves the ductility of the weld [13, 28]. The large oxygen in the weld forms inclusions and these inclusions are supposed to be harmful for ductility $[29,30]$. However, the shape and size of inclusions may also affect the ductility. The elongation is reduced with the increase of FeMn 


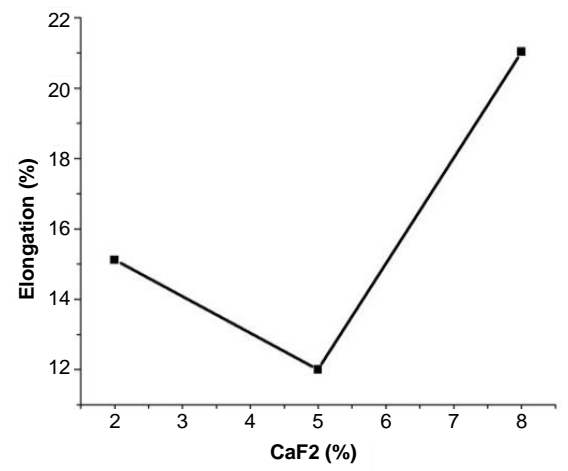

Fig. 11. Effect of $\mathrm{CaF}_{2}$ on elongation of the welds

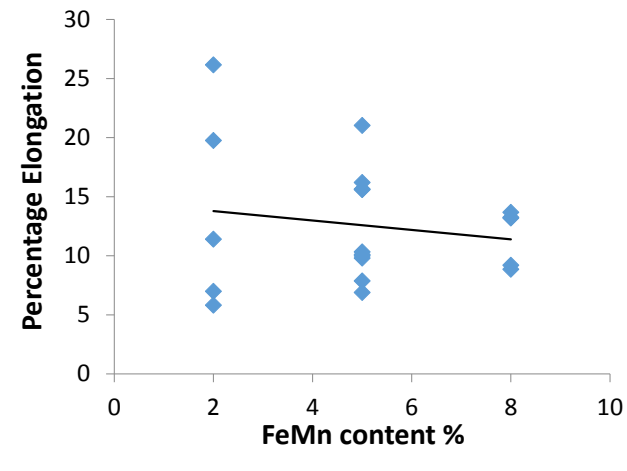

Fig. 12. Effect of FeMn content on elongation of the welds

content. This is shown in Fig. 12. This may be attributed to the increase in hardness because of increasing FeMn content in the flux. The transfer of Mn content in the weld also depends upon the FeMn proportion in the flux. The Mn content in the weld promotes fine grained structure which increases the strength and hardness but reduces the ductility of the weld.

The effect of FeMn on elongation at various levels of $\mathrm{CaF}_{2}$ is shown in Fig. 13. It shows that the elongation has only increasing trend, when $\mathrm{CaF}_{2}$ lies at a level of $2 \%$. For other two levels of $\mathrm{CaF}_{2}$, elongation decreases. The correlation of $\mathrm{Si}$ content with elongation shows that the elongation is increased with the increase of Si content. This is in agreement with the literature [8]. However, silicon may also cause a loss of ductility, if it is higher than $0.5 \%$. The effect of carbon equivalent on elongation is shown in Fig. 14. This can be seen

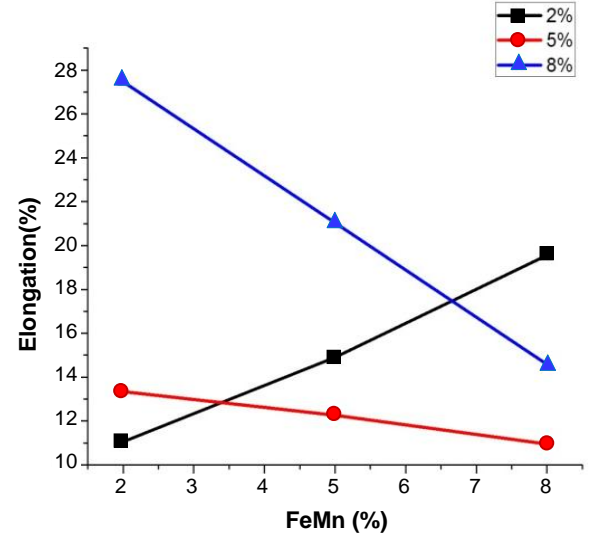

Fig. 13. Effect of FeMn on elongation at various levels of $\mathrm{CaF}_{2}$

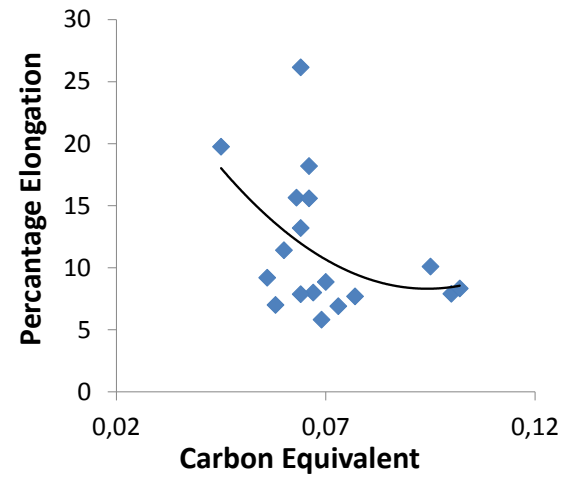

Fig. 14. Effect of carbon equivalent on elongation of the welds 
from this Figure that with the increase of carbon equivalent, the elongation is reduced. It may be attributed to increase in hardness and brittleness with increasing carbon equivalent. The basicity index of the flux also has a certain effect on elongation of the weld. The percentage elongation increases with increase of basicity index of the flux as shown in Fig. 15. This can be attributed to the low oxygen in the weld with increasing the basicity index of the flux. The deviation of the fitted line in Fig. 15 may again be because of very low change in BI of the flux. As all the developed fluxes were acidic in nature. High oxygen in the weld promotes brittleness in the weld metal [13]. The correlation of percentage elongation with the weld oxygen content shows that the elongation is slightly increased with the increase in weld oxygen content. A negative $\Delta \mathrm{Mn}$ quantity can be considered as an indirect measure of weld oxygen content. This has been shown in the Fig. 16. The weld elongation is low when the oxygen in the weld is either very high or very low. The Fig. 15 shows that the trend line is deviated from the reference points. This variation may be attributed to the actual weld oxygen present in the weld. The transfer of elements cannot be decided by the equilibrium equations as the temperature during SAW is very high and it is not certain to ensure that the equilibrium has been achieved.

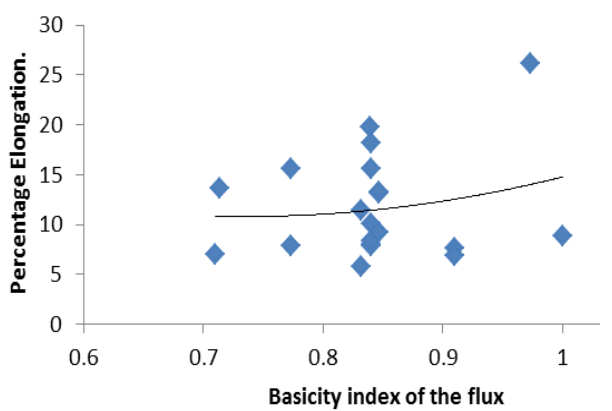

Fig. 15. Effect of basicity index on elongation of the welds

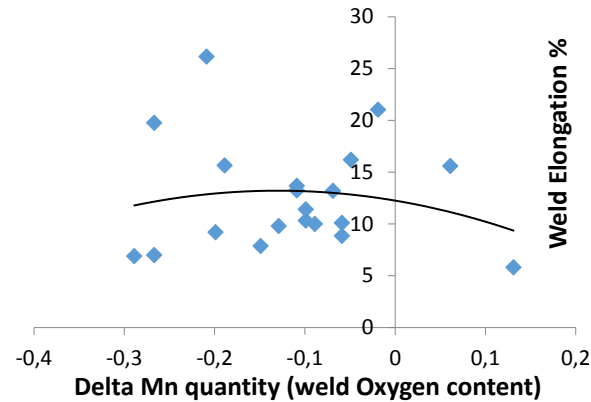

Fig. 16. Correlation of welds UTS with $\Delta \mathrm{Mn}$ quantity

\section{Correlation of $\mathrm{Mn}, \mathrm{Ni}$ and $\mathrm{Si}$ contents with elongation}

The correlation of weld $\mathrm{Mn}$ content shows that the elongation remains almost constant upto $0.4 \%$ addition of $\mathrm{Mn}$ to the weld but after that it is reduced. This is in agreement with the literature. This has been shown in Fig. 17. The effect of Si content on the elongation of the welds shows that it increases with the increase of weld $\mathrm{Si}$ transfer as shown in Fig. 18. This is inagreement with the literature as only high silicon content greater than $0.5 \%$ reduces the ductility [12]. The elongation is not much affected with Ni content in the weld. This can be seen from Fig. 19. 


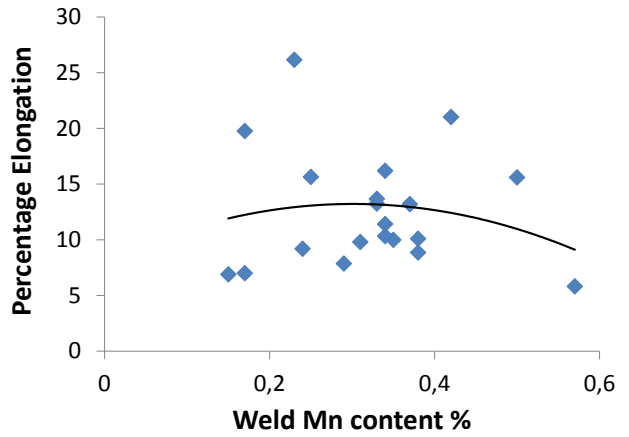

Fig. 17. Correlation of elongation with weld Mn transfer

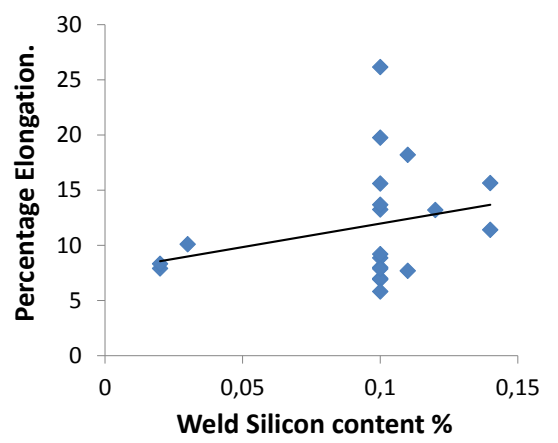

Fig. 18. Correlation of elongation with weld $\mathrm{Si}$ transfer

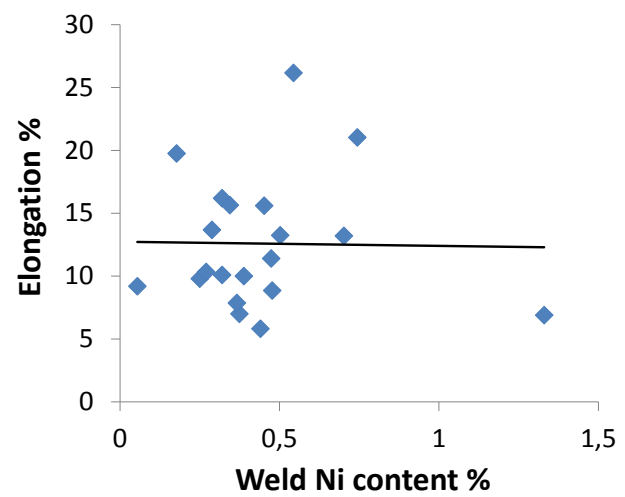

Fig. 19. Correlation of elongation with weld Ni transfer

\section{Interaction effect of the flux additives on UTS and percentage elongation}

The interaction effect of FeMn and NiO contents on UTS of the welds is shown in Fig. 20. This shows that the UTS decrease with increasing both the FeMn and $\mathrm{NiO}$ contents in the flux. The maximum value is observed, when $\mathrm{NiO}$ content is at lower level and FeMn at higher level. The minimum UTS occur when both the factors are at higher level. The 3D surface graph for combined effect of $\mathrm{CaF}_{2}$ and FeMn is shown in Fig. 21. This shows that the elongation increases with the increase of both $\mathrm{CaF}_{2}$ and $\mathrm{FeMn}$ contents in the flux. It shows that the maximum value of the elongation occurs at $8 \%$ $\mathrm{CaF}_{2}$ and $2 \%$ FeMn levels and it is minimum when $\mathrm{CaF}_{2}$ and $\mathrm{FeMn}$ both are at $2 \%$ level. 


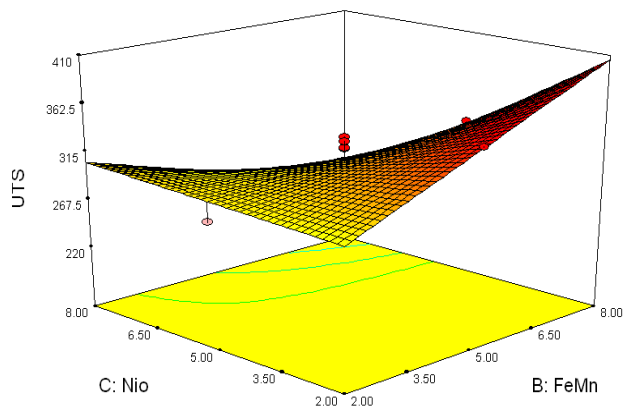

Fig. 20. Interaction effect of $\mathrm{NiO}$ and $\mathrm{FeMn}$ on UTS of the welds

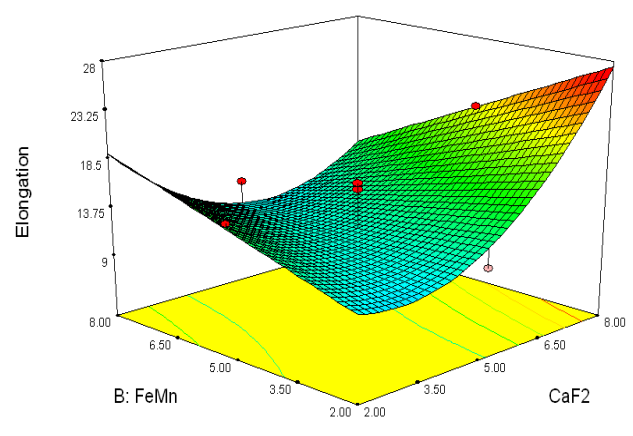

Fig. 21. Interaction effect of $\mathrm{CaF}_{2}$ and FeMn on percentage elongation of the welds

\section{Confirmatory Tests}

Confirmatory tests were conducted using randomly selected flux additives from the given range of fluxes to validate the regression model and to ensure the reliability of the predicted values. From the experimental values it has been found that percentage error for each response is in the acceptable limit from the experimental point of view. The predicted and actual values of the ultimate tensile strength and percentage elongation are given in Table 7.

Table 7.

The predicted and experimental values of UTS and percentage Elongation

\begin{tabular}{|c|c|c|c|c|c|c|c|c|c|}
\hline S.No. & $\begin{array}{c}\mathrm{CaF}_{2} \\
\%\end{array}$ & $\begin{array}{c}\text { FeMn } \\
\%\end{array}$ & $\begin{array}{c}\mathrm{NiO} \\
\%\end{array}$ & $\begin{array}{c}\text { Predicted } \\
\text { UTS }\end{array}$ & $\begin{array}{c}\text { Experimental } \\
\text { value of UTS }\end{array}$ & $\begin{array}{c}\text { Error } \\
\%\end{array}$ & $\begin{array}{c}\text { Predicted } \\
\text { value of \% } \\
\text { Elongation }\end{array}$ & $\begin{array}{c}\text { Experimental } \\
\text { value of } \\
\text { Elongation }\end{array}$ & $\begin{array}{c}\text { Error } \\
\%\end{array}$ \\
\hline 1 & 2 & 2 & 5 & 169.50 & 176.0 & 3.83 & 11.08 & 11.86 & 7.03 \\
\hline 2 & 2 & 2 & 5 & 169.50 & 178.0 & 5.01 & 11.08 & 11.50 & 4.33 \\
\hline 3 & 5 & 2 & 8 & 305.64 & 289.0 & 5.44 & 8.83 & 8.40 & 4.86 \\
\hline 4 & 5 & 2 & 8 & 305.64 & 312.0 & 2.08 & 8.83 & 9.20 & 4.19 \\
\hline
\end{tabular}

\section{Conclusions}

Based on the above experimental work, the following conclusions can be safely drawn.

1. $\mathrm{CaF}_{2}$ and FeMn both as individual factors show the positive effect on ultimate tensile strength. These have synergistic effect on tensile strength individually but as a mixture, these have anti synergistic effect.

2. The ultimate tensile strength increases with $\mathrm{CaF}_{2}$ additive of the flux to a certain extent and after that it is slightly reduced.

3. The tensile strength of the welds increases with increasing basicity index of the flux and the carbon equivalent of the welds. 
4. The tensile strength increases with the weld Mn content but after $0.4 \%$ Mn content, the tensile strength is reduced. The tensile strength has a decreasing trend with $\mathrm{Ni}$ and $\mathrm{Si}$ weld contents. However, it increases with increase of basicity index of the flux.

5. The tensile strength increases with FeMn content in the flux, while it decreases with $\mathrm{NiO}$ additive in the flux. The tensile strength of the weld is reduced with the increasing oxygen in the weld.

6. The percentage elongation of the weld firstly decreases to a certain extent and after that it increases with increasing $\mathrm{CaF}_{2}$ content. Nonetheless, with FeMn additive, it decreases. The correlation of Mn content with the elongation shows that it remains almost constant up to $0.4 \%$ of Mn content but after that it is decreased. The Ni proportion transfer does not show any effect on elongation. However, the elongation is increased with weld Si content.

7. The basicity index of the flux shows a positive effect on percentage elongation. Nevertheless, it is decreased with increase of carbon equivalent.

8. The percentage elongation of the weld is low when the oxygen content is either very high or very low.

Manuscript received by Editorial Board, December 01, 2015;

final version, March 13, 2016.

\section{References}

[1] R.S. Parmar. Welding Processes and Technology. Khanna Publisher, New Delhi, 1992.

[2] N. Murugan and V. Gunaraj. Prediction and control of weld bead geometry and shape relationships in submerged arc welding of pipes. Journal of Materials Processing Technology, 168(3):478-487, 2005.

[3] P.T. Houldcroft. Submerged-arc welding. Woodhead Publishing, Cambridge, 1989.

[4] P. Kanjilal, T.K. Pal, and S.K. Majumdar. Combined effect of flux and welding parameters on chemical composition and mechanical properties of submerged arc weld metal. Journal of Materials Processing Technology, 171(2):223-231, 2006.

[5] P. Kanjilal, T.K Pal, and S.K. Majumdar. Prediction of element transfer in submerged arc welding. Welding Journal, 86(5):135-146, 2007.

[6] P. Kanjilal, S.K. Majumdar, and T.K. Pal. Prediction of acicular ferrite from flux ingredients in submerged arc weld metal of C-Mn steel. ISIJ International, 45(6):876-885, 2005.

[7] N.D. Pandey, A. Bharti, and S.R. Gupta. Effect of submerged arc welding parameters and fluxes on element transfer behaviour and weld-metal chemistry. Journal of Materials Processing Technology, 40(1):195-211, 1994.

[8] J.H. Palm. How fluxes determine the metallurgical properties of SAW. Welding Research Supplement, pages 358-360, 1972.

[9] A.R. Bell. Properties of HY-130 weldment produced by weld pool filler synthesis. Master Thesis, Ohio State University, Ohio, 1985. 
[10] O.P. Modi, N. Deshmukh, D.P. Mondal, A.K. Jha, A.H. Yegneswaran, and H.K. Khaira. Effect of interlamellar spacing on the mechanical properties of $0.65 \%$ carbon steel. Materials Characterization, 46(5):347-352, 2001.

[11] O. Grong, T.A. Siewert, G.P. Martins, and D.L. Olson. A model for the silicon-manganese deoxidation of steel weld metals. Metallurgical and Materials Transactions A, 17(10):1797$1807,1986$.

[12] D.J. Abson and R.J. Pargeter. Factors influencing as-deposited strength, microstructure, and toughness of manual metal arc welds suitable for C-Mn steel fabrications. International Metals Reviews, 31(1):141-196, 1986.

[13] N.N. Potapov. Oxygen effect on low-alloy steel weld metal properties. Welding Research Supplement, pages 367-370, 1993.

[14] C.S. Chai and T.W. Eagar. Slag metal reactions in binary CaF2-metal oxide welding fluxes. Welding Journal, 61(7):229-232, 1982.

[15] A. Joarder, S.C. Saha, and A.K. Ghose. Study of submerged arc weld metal and heat-affected zone microstructures of a plain carbon steel. Welding Research Supplement, 22(6):141-146, 1991.

[16] J.F. Lancaster. The metallurgy of welding. Allen and Unwin, London, 4 edition, 1987.

[17] K. Easterling. Introduction to the physical metallurgy of welding. Butterworth-Heinemann, London, 1992.

[18] L.-E. Svensson. Control of microstructures and properties in steel arc welds, volume 1. CRC Press, Boca Raton, 1993.

[19] V. Kumar. Modeling of weld bead geometry and shape relationships in submerged arc welding using developed fluxes. Jordan Journal of Mechanical and Industrial Engineering, 5(5):461470, 2011

[20] S. Jindal. Development of submerged arc welding fluxes for welding of structural steels. Ph.D Thesis, MMU, Ambala, Haryana, India, 2013.

[21] T.W. Eagar. Sources of weld metal oxygen contamination during submerged arc welding. Welding Journal, 57(3):76-80, 1978.

[22] K. Bang, C. Park, H. Jung, and J. Lee. Effects of flux composition on the element transfer and mechanical properties of weld metal in submerged arc welding. Metals and Materials International, 15(3):471-477, 2009.

[23] E. Surian and T. Boniszewski. Effect of manganese and type of current on the properties and microstructure of all-weld-metal deposited with E7016-1 electrodes. Welding Research Supplement, 71(9):348-363, 1992.

[24] A.M. Paniagua-Mercado, Víctor M. López-Hirata, A.F. Méndez-Sánchez, and M.L. SaucedoMuñoz. Effect of active and nonactive fluxes on the mechanical properties and microstructure in submerged-arc welds of A-36 steel plates. Materials and Manufacturing Processes, 22(3):295297, 2007.

[25] G.M. Evans. Effect of manganese on weld microstructure and properties of all-weld-metal deposits. Welding Journal, 59(3):67-75, 1980.

[26] F.S. Jaberi and A.H. Kokabi. Influence of nickel and manganese on microstructure and mechanical properties of shielded metal arc-welded API-X80 steel. Journal of Materials Engineering and Performance, 21(7):1447-1454, 2012.

[27] T. Boniszewski. Self-shielded arc welding. Elsevier, 1992.

[28] R.D. Stout and W.D. Doty. Weldability of steels. Welding Research Council, New York, 3 edition, 1978.

[29] A. Ghosh. Secondary steelmaking: principles and applications. CRC Press, Boca Raton, 2000.

[30] A. Nicholoson and T. Gladman. Nonmetallic inclusion and development in secondary steel making. Iron Making Steel Making, 13(2):53-69, 1986. 
Efekt składu topnika na wydłużenie procentowe i wytrzymałość na rozciąganie spawów przy spawaniu łukiem krytym

Streszcze ni e

W studium eksperymentalnym, przedstawionym w pracy, pokazano wpływ domieszek $\mathrm{CaF}_{2}$, FeMn i NiO do podstawowego składu topnika na wytrzymałość na rozciąganie i procentowe wydłużenie metalu spawu. Celem studium było opracowanie topnika odpowiedniego dla stali niskowęglowej, który zapewnia wysoką wytrzymałości na rozciąganie, wytrzymałość na udary i plastyczność. Ściegi spawów wykonano metodą spawania łukiem krytym. Opracowano model matematyczny wydłużenia procentowego i wytrzymałości na rozciąganie (UTS) dla spawów ze stali niskowęglowej. Zbadano korelację między wymienionymi charakterystykami mechanicznymi a transferem pierwiastków do spawu. Wyznaczono także wpływ zawartości tlenu na wydłużenie spawu i ostateczną wytrzymałość na rozciąganie. W badaniach doświadczalnych wykazano, że domieszki $\mathrm{CaF}_{2}$ oraz $\mathrm{NiO}$ są istotnymi czynnikami wpływającymi na wytrzymałość na rozciąganie, podczas gdy domieszka FeMn nie ma istotnego wpływu. Oceniono także wpływ współczynnika zasadowości topnika i równoważnika węglowego spawu na wydłużenie procentowe spawu. 